\title{
Evaluation of the Use of Vinasse as a Biostimulation Agent for the Biodegradation of Oily Sludge in Soil
}

\author{
Sérgio Henrique Rezende Crivelaro ${ }^{1}$, Adriano Pinto Mariano ${ }^{1 *}$ Luis Tadeu Furlan ${ }^{2}$, \\ Renato Almeida Gonçalves ${ }^{2}$, Paulo Negrais Seabra ${ }^{3}$ and Dejanira de Franceschi de \\ Angelis ${ }^{1}$ \\ ${ }^{1}$ Departamento de Bioquímica e Microbiologia; Instituto de Biociências; Universidade Estadual Paulista; Av. 24-A; \\ 1515; C. P.: 199; 13506-900; Rio Claro - SP - Brasil. ${ }^{2}$ Refinaria de Paulínia-REPLAN (Petrobras); Paulínia - SP - \\ Brasil. ${ }^{3}$ Centro de Pesquisas e Desenvolvimento Leopoldo Américo Miguez de Mello (Petrobras); Rio de Janeiro - \\ RJ - Brasil
}

\begin{abstract}
This work aimed to study the effect of vinasse on the biodegradation in soil of oily sludge from the Replan-Petrobras oil refinery. The Bartha respirometric method was used to verify the efficiency of the treatments with soil, oily sludge $(7$ and $14 \% \mathrm{~m} / \mathrm{m})$ and soil moisture adjustment with or without vinasse $(0.11 \mathrm{~mL} / \mathrm{g}$ dry soil) for 121 days. Although an increase in the soil microbial population was obtained with the vinasse, it demonstrated not to be adequate to enhance the biodegradation efficiency of the oily sludge in soil, since there was no difference between the $\mathrm{CO}_{2}$ produced from treatments with or without vinasse after the complete consumption of the vinasse. Thus, the use of vinasse as an amendment to biodegradation processes showed not to be efficient under the studied conditions.
\end{abstract}

Key words: biodegradation, soil, oily sludge, vinasse, landfarming

\section{INTRODUCTION}

The oil industry is responsible for the generation of high amounts of oily and viscous residues, which are formed during the production, transportation and refining. Such residues, called oily sludge, are basically composed of oil, water, solids, and their characteristics, such as varied composition, make their reutilisation very difficult, and confer on them high recalcitrance. Moreover, incineration of this residue is not recommended due to high energy costs, the potential risk of air pollution and the persistence of PAHs (Ururahy et al., 1998). Thus studies must be carried out aiming the improvement of the current suitable technologies or the development of new ones.

The landfarming system is the most world-wide known technology used to treat the oily sludge. This system is designed to ensure the aerobic biodegradation of the residue in the soil superficial layer (Kataoka, 2001). However, this technology demands long process times and large areas and there is a potential risk of groundwater contamination if the landfarming is not well constructed.

Due to the low biodegradation efficiency observed in the treatments where the oily sludge is mixed with soil (landfarming, biopile, and composting)

*Author for correspondence: adrianomariano@yahoo.com.br 
(Bossert et al., 1984; Mishra et al., 2001; Juteau et al., 2003; Ayotamuno et al., 2007; MachínRamírez et al., 2008), nutritional amendment is one of the possibilities to tackle this problem (Brown1 Hahn and Loehr, 1992; Chokshi and Nelson, 2003; Mrayyan and Battikhi, 2004). According to Ururahy et al. (1998), oily sludges possess limited amounts of nitrogen and phosphate, and most of the nitrogen is not available, since it is part of complex structures, relatively inaccessible to microorganisms.

In Brazil, it is very common to dispose vinasse (a by-product of the alcohol distillation process with fertilisation characteristics) in agricultural fields, a process called ferti-irrigation, as a partial or total substitute for mineral fertilisers, mainly potassium. In general, to produce one litre of alcohol, 10 to 15 litres of vinasse are produced, depending on sugar cane quality and the industrial process (Cortez et al., 1992), which corresponds to approximately 170 billion litres per year of this residue in Brazil (Agrianual, 2004).

Considering that the ethanol production in Brazil is in expansion due to a rising internal and world- wide demand for alternative energy sources and that soils have a limited support capability to receive the vinasse, the search for additional application for the vinasse is very important. Thus, this work evaluated the potential use of vinasse as a biostimulation agent for the biodegradation of oily sludge in soil.

\section{MATERIALS AND METHODS}

\section{Oily sludge and vinasse characteristics}

The oily sludge was obtained from Replan/Petrobras oil refinery (Paulinia/SP/Brazil) prior to its disposal in the landfarming system. Vinasse was collected at Usina América (Assis/SP/Brazil). Tables 1 and 2 show the physicochemical characteristics of the oily sludge and vinasse, respectively. The analyses were performed by Icasa laboratory (Instituto Campineiro de Análise de Solo e Adubo - Icasa), according to the methodology proposed by Embrapa (1997).

$\underline{\text { Table } 1 \text { - Oily sludge characteristics. }}$

\begin{tabular}{|c|c|c|}
\hline $\mathrm{N}$ & $\%$ & 0.53 \\
\hline total $\mathrm{P}\left(\mathrm{P}_{2} \mathrm{O}_{5}\right)$ & $\%$ & 0.0908 \\
\hline $\mathrm{K}$ & $\mathrm{K}_{2} \mathrm{O}(\%)$ & 0.025 \\
\hline $\mathrm{Ca}$ & $\%$ & 0.29 \\
\hline $\mathrm{Mg}$ & $\%$ & 0.11 \\
\hline $\mathrm{S}$ & $\%$ & 0.32 \\
\hline $\mathrm{Fe}$ & $\%$ & 0.69 \\
\hline $\mathrm{Mn}$ & $\%$ & 0.0138 \\
\hline $\mathrm{Cu}$ & $\%$ & 0.00275 \\
\hline $\mathrm{Zn}$ & $\%$ & 0.0683 \\
\hline $\mathrm{B}$ & $\%$ & 0.005 \\
\hline $\mathrm{Na}$ & $\%$ & 0.13 \\
\hline $\mathrm{Co}$ & $\%$ & 2.50 \\
\hline Mo & $\%$ & $-^{\mathrm{a}}$ \\
\hline $\mathrm{Al}$ & $\%$ & 0.71 \\
\hline $\mathrm{Ba}$ & $\%$ & 0.005211 \\
\hline $\mathrm{Cd}$ & $\%$ & 0.000028 \\
\hline $\mathrm{Cr}$ & $\%$ & 0.005781 \\
\hline $\mathrm{Ni}$ & $\%$ & 0.001414 \\
\hline $\mathrm{Pb}$ & $\%$ & 0.001323 \\
\hline moisture $65^{\circ} \mathrm{C}$ & $\%$ & 80.86 \\
\hline moisture $105^{\circ} \mathrm{C}$ & $\%$ & 81.33 \\
\hline organic matter & $\%$ & 63.85 \\
\hline ashes & $\%$ & 36.15 \\
\hline density & $\mathrm{g} / \mathrm{mL}$ & 1.03 \\
\hline $\mathrm{C} / \mathrm{N}$ ratio & & 66.93 \\
\hline $\mathrm{pH}$ & & 7.20 \\
\hline
\end{tabular}

${ }^{a}$ not detected. 
Table 2 - Vinasse characteristics.

\begin{tabular}{cccccc}
\hline $\mathrm{N}$ & $\%$ & 0.18 & $\mathrm{~B}$ & $\%$ & 0.0015 \\
total $\mathrm{P}\left(\mathrm{P}_{2} \mathrm{O}_{5}\right)$ & $\%$ & 0.009 & $\mathrm{Na}$ & $\%$ & 0.01 \\
$\mathrm{~K}$ & $\mathrm{~K}_{2} \mathrm{O} \%$ & 0.48 & $\mathrm{Co}$ & $\%$ & $-^{\mathrm{a}}$ \\
$\mathrm{Ca}$ & $\%$ & 0.13 & $\mathrm{Mo}$ & $\%$ & $-^{\mathrm{a}}$ \\
$\mathrm{Mg}$ & $\%$ & 0.0388 & $\mathrm{Al}$ & $\%$ & 0.0025 \\
$\mathrm{~S}$ & $\%$ & 0.12 & organic matter & $\%$ & 2.88 \\
$\mathrm{Fe}$ & $\%$ & 0.00725 & $\mathrm{C} / \mathrm{N}$ ratio & & 8.89 \\
$\mathrm{Mn}$ & $\%$ & 0.00075 & density & $\mathrm{g} / \mathrm{mL}$ & 1.01 \\
$\mathrm{Cu}$ & $\%$ & $-^{\mathrm{a}}$ & & & 4.24 \\
$\mathrm{Zn}$ & $\%$ & 0.0005 & & & \\
\hline
\end{tabular}

${ }^{a}$ not detected.

\section{Soil respirometric experiment}

The soil sample was collected from a loan area at a landfill in Rio Claro/SP/Brazil. Until performing the biodegradation experiment, the samples were stored at $5{ }^{\circ} \mathrm{C}$. Table 3 summarises some physicochemical characteristics of the soil sample. The physicochemical analyses were performed by Icasa laboratory according to the methodology proposed by Embrapa (1997). In order to verify the influence of the vinasse in the biodegradation of the oily sludge, a batch biodegradation experiment (121 days) was carried out in Bartha biometer flasks $(250 \mathrm{~mL})$ used to measure the microbial $\mathrm{CO}_{2}$ production (Bartha and Pramer, 1965; Régis and Bidoia, 2005; Inazaki et al., 2004; Mariano et al., 2008a-c and 2009b).

Table 4 shows the treatments simulated in the respirometric experiments. The quantity of water or vinasse added to adjust the soil moisture to $64.2 \%$ of the soil field capacity was $0.11 \mathrm{~mL} / \mathrm{g}$ dry soil. For each treatment, the biometer flasks were prepared in triplicates $(3 \times 50 \mathrm{~g}$ of soil) and incubated at $27{ }^{\circ} \mathrm{C}$ in the dark. The $\mathrm{CO}_{2}$ produced was trapped in a $10.0 \mathrm{~mL}$ solution of $\mathrm{KOH}(0.2$ $\mathrm{N})$, located in the side-arm of the biometer. This solution was periodically withdrawn by syringe, and the amount of carbon dioxide absorbed was then measured by titrating the residual $\mathrm{KOH}$ [after the addition of barium chloride solution $(1 \mathrm{~mL} ; 1.0$ $\mathrm{N})$ used to precipitate the carbonate ions] with a standard solution of $\mathrm{HCl}(0.1 \mathrm{~N})$. During this procedure, the biometers were aerated for 1.5 minute through the ascarite filters. At the end of the experiment, replicates of each treatment were thoroughly mixed together for microbiological analysis.

Table 3 - Soil characteristics.

\begin{tabular}{|c|c|c|c|c|c|}
\hline & & & & & $\left(\mathbf{m m o l c} / \mathbf{d m}^{3}\right)$ \\
\hline $\mathrm{pH}\left(\mathrm{CaCl}_{2}\right)$ & & 4.1 & $\mathrm{Ca}$ & & 8.0 \\
\hline organic matter (\%) & & 0.5 & $\mathrm{Mg}$ & & 5.0 \\
\hline $\mathrm{P}(\%)$ & & 0.0003 & $\mathrm{Al}$ & & 21.0 \\
\hline moisture (\%) & & 12.0 & $\mathrm{~K}$ & & 0.6 \\
\hline field capacity $\left(\mathrm{g} \mathrm{H}_{2} \mathrm{O} / \mathrm{g}\right.$ soil) & & 0.36 & & & \\
\hline \multicolumn{6}{|l|}{ grain size distribution $(\%)$} \\
\hline sand & & 47.2 & & & \\
\hline silt & & 22.7 & & & \\
\hline clay & & 30.1 & & & \\
\hline \multicolumn{6}{|l|}{ micronutrients (\%) } \\
\hline $\mathrm{Na}$ & $\mathrm{Fe}$ & $\mathrm{Mn}$ & $\mathrm{Cu}$ & $\mathrm{Zn}$ & B \\
\hline 0.0007 & 0.0004 & 0.00011 & 0.00001 & 0.00007 & 0.000048 \\
\hline
\end{tabular}


Table 4 - Respirometric experiments.

\begin{tabular}{cl}
\hline treatment & experimental condition \\
\hline 1 & soil + water \\
2 & soil + vinasse \\
3 & soil + oily sludge $(7 \% \mathrm{~m} / \mathrm{m})+$ water \\
4 & soil + oily sludge $(7 \% \mathrm{~m} / \mathrm{m})+$ vinasse \\
5 & soil + oily sludge $(14 \% \mathrm{~m} / \mathrm{m})+$ water \\
6 & soil + oily sludge $(14 \% \mathrm{~m} / \mathrm{m})+$ vinasse \\
\hline
\end{tabular}

Total heterotrophic bacteria and fungi were counted by using the pour plate technique on Plate Count Agar (PCA) and Potato Dextrose Agar (PDA + plus antibiotic), respectively. The plate counts were performed as follows: samples of $1 \mathrm{~g}$ of soil were added to $9 \mathrm{~mL}$ of $0.85 \%$ sterile saline solution in test tubes and agitated mechanically for 2 minutes. After appropriate serial dilutions, $1 \mathrm{~mL}$ of the suspension were spread over the surface of duplicate petri dishes and incubated for $48 \mathrm{~h}$ at 35 ${ }^{\circ} \mathrm{C}$ (bacteria) or $28{ }^{\circ} \mathrm{C}$ (fungi). The total heterotrophic bacteria count was carried out at the beginning and at end of the respirometric experiment.

\section{RESULTS AND DISCUSSION}

The daily $\mathrm{CO}_{2}$ productions in the respirometric experiment are represented in Figures 1 to 3, where each error bar represents one SD (standard deviation) of three replicates. The evolution of the $\mathrm{CO}_{2}$ production in treatment 2 (soil + vinasse) (Fig. 1) showed that the vinasse was practically totally biodegraded in approximately 40 days after being applied to the soil. When considering the treatments with oily sludge and vinasse (Fig.2 and 3 ), a similar behaviour was observed, i.e. the $\mathrm{CO}_{2}$ production in the treatments with vinasse initially differentiate from the controls and after similar period (40 days), it decreased until reaching values next to the controls. Thus, since there was no difference between the $\mathrm{CO}_{2}$ produced from the treatments with or without vinasse after the complete consumption of the vinasse, it showed that the vinasse did not biostimulate the biodegradation of the oily sludge at the mineralization level. It is important to emphasise that mineralization studies involving measurements of total $\mathrm{CO}_{2}$ production can provide excellent information on the biodegradability potential of hydrocarbons (Balba et al., 1998).

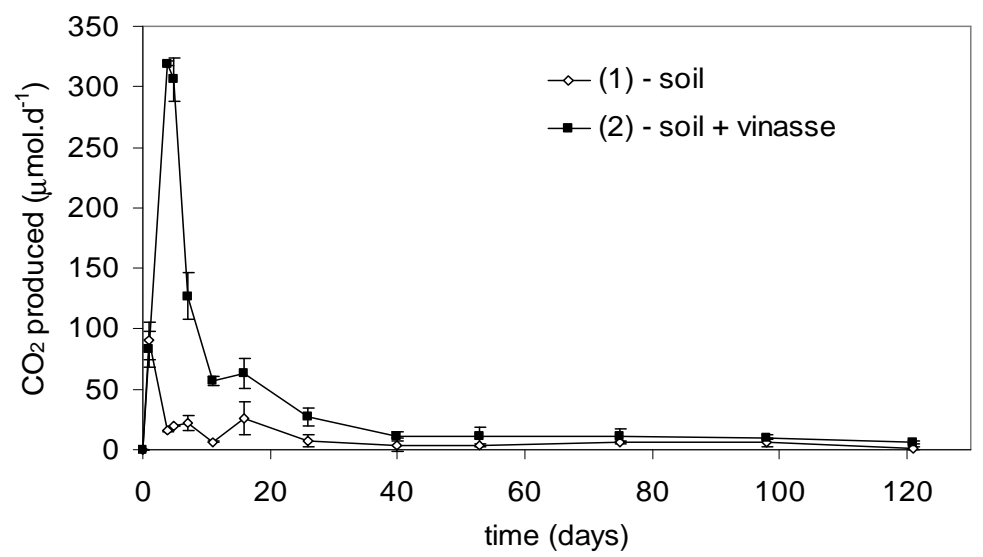

Figure $1-\mathrm{CO}_{2}$ production for treatments 1 and 2. 


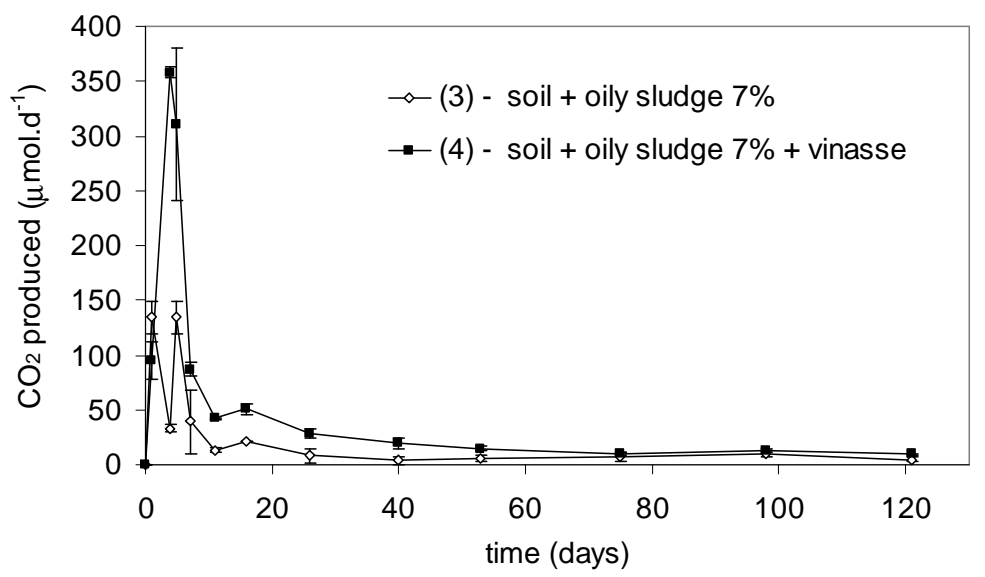

Figure $2-\mathrm{CO}_{2}$ production for treatments 3 and 4.

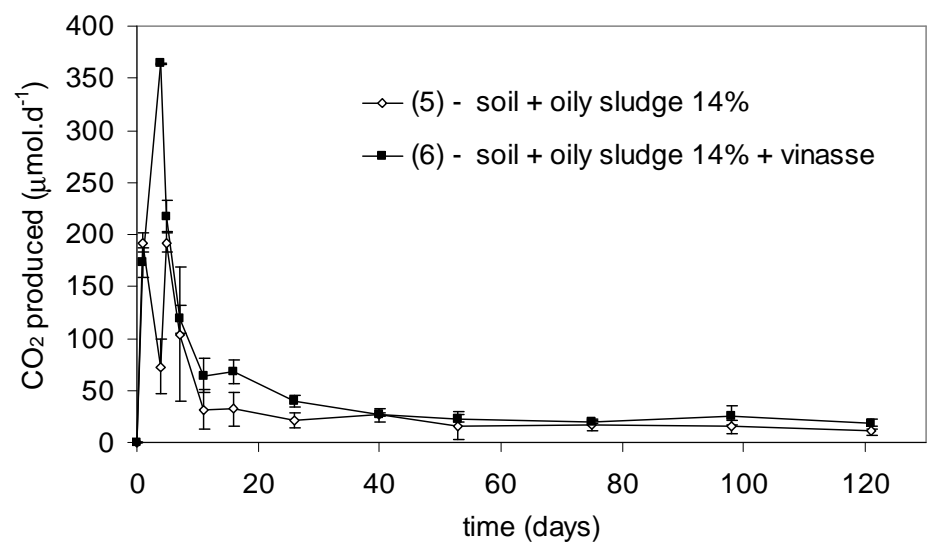

Figure $3-\mathrm{CO}_{2}$ production for treatments 5 and 6.

The microorganisms (total heterotrophic bacteria and fungi) counts carried out at the initial and final times of the respirometric experiment are shown in Figures 4 and 5. In almost all counts, the treatments with vinasse had a microbial population greater at the final time than the controls without vinasse. The exception was verified in the total heterotrophic bacteria count for treatments with an oily sludge concentration of $7 \%$ (treatments 3 and 4, Fig. 5). It indicated that generally vinasse had a positive effect on the soil microbial population, overcoming the toxicity of the oily sludge that could have negative effects on the microbiot, as observed by Mielniczuk (1991).
The increase in the soil microbial population caused by the vinasse was also observed by Prata et al. (2001) and Mariano et al. (2009a) in their biodegradation experiments. However, as observed by Hickman and Novak (1989), the total microbial biomass could be a poor predictor for determining the biodegradation potential, mainly because the active biomass could differ in species composition and in metabolic regimes. Certainly these additional microorganisms preferentially biodegraded the more labile carbon sources as the glycerol present in the vinasse (Rodella et al., 1983; Prata et al., 2001); otherwise, a marked decrease in the $\mathrm{CO}_{2}$ production after the consumption of the vinasse would not be observed. 


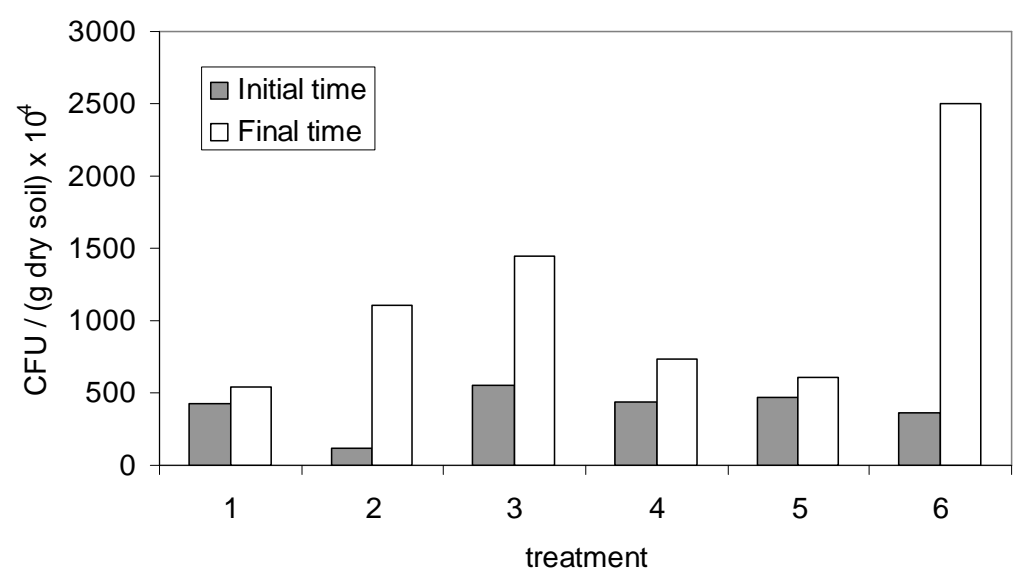

Figure 4 - Total heterotrophic bacteria at initial and final time of the treatments.

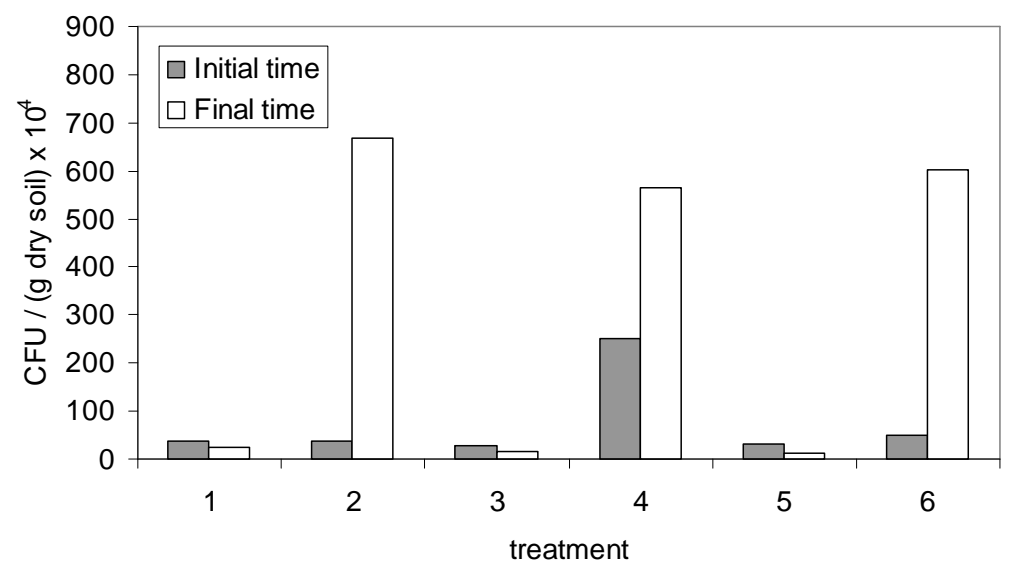

Figure 5 - Total fungi at initial and final time of the treatments.

\section{CONCLUSIONS}

Although an increase in the soil microbial population was obtained with the vinasse, it demonstrated not to be adequate to enhance the bioremediation efficiency of the oily sludge at the mineralization level. Thus, the use of vinasse as an amendment to biodegradation processes showed not to be efficient under the studied conditions.

\section{ACKOWLEDGMENTS}

The authors acknowledge Agência Nacional do Petróleo, Gás Natural e Biocombustíveis (ANP) (PRH-05) for the financial support, and REPLAN/PETROBRAS and Usina América for supplying oily sludge and vinasse, respectively. 


\section{RESUMO}

Este trabalho objetivou estudar o efeito da vinhaça na biodegradação em solo da borra oleosa proveniente da refinaria de petróleo ReplanPetrobras. Foi utilizado o método respirométrico de Bartha para verificar a eficiência de tratamentos constituídos de solo, borra oleosa nas concentrações 7 e $14 \%(\mathrm{~m} / \mathrm{m})$ e ajuste da umidade do solo com e sem vinhaça $(0,11 \mathrm{~mL} / \mathrm{g}$ solo seco) durante 121 dias. Embora a adição da vinhaça tenha proporcionado um aumento da população microbiana nos tratamentos, esta não se mostrou adequada para aumentar a eficiência de biodegradação da borra oleosa em solo, uma vez que não houve diferença entre o $\mathrm{CO}_{2}$ produzido nos tratamentos com ou sem vinhaça após o consumo total da vinhaça. Assim, o uso da vinhaça como agente estimulante em processos de biodegradação mostrou-se ineficiente nas condições estudadas.

\section{REFERENCES}

Agrianual (2004), Anuário da agricultura brasileira. FNP, São Paulo.

Ayotamuno, M. J., Okparanma, R. N., Nweneka, E. K. Ogaji, S. O. T. and Probert, S. D. (2007), Bioremediation of a sludge containing hydrocarbons. Applied Energy, 84 (9), 936-943.

Balba, M. T., Al-Awadhi, N. and Al-Daher, R. (1998), Bioremediation of oil-contaminated soil: microbiological methods for feasibility assessment and field evaluation. Journal of Microbiological Methods, 32, 155-164.

Bartha, R. and Pramer, D. (1965), Features of a flask and method for measuring the persistence and biological effects of pesticides in soil. Soil Sci. 100, 68-70.

Bossert, I., Kachel, W. M., Bartha, R. (1984), Fate of hydrocarbons during oily sludge disposal in soil. Appl. Environ. Microbiol., 47 (4), 763-767.

Chokshi, B. G., Nelson, Y. M. (2003), Optimization of high-strength hydrocarbon biodegradation using respirometry. Proceedings of the Seventh International In Situ and On-Site Bioremediation Symposium. Available http://works.bepress.com/ynelson/11.

Cortez, L., Magalhães, P. and Happi, J. (1992), Principais subprodutos da agroindústria canavieira e sua valorização. Revista Brasileira de Energia, 2 (2), 111.
Embrapa - Empresa Brasileira de Pesquisa Agropecuária (1997), Serviço Nacional de Levantamento e Conservação de Solos. Manual de Métodos de Análises de Solos. Rio de Janeiro.

Hahn, W.J. and Loehr, R.C. (1992), Biological treatment of petroleum oily sludges. SPE - Society of Petroleum Engineers - Permian Basin Oil and Gas Recovery Conference, Texas, p.519-530.

Hickman, G. T. and Novak, J. T. (1989), Relationship between subsurface biodegradation rates and microbial density. Environ. Sci. Technol., 23, 525532.

Inazaki, T. H., Pião, A. C. S. and Bidoia, E. D. (2004), Treatment of simulated wastewater containing nphenyl-n-isopropyl-p-phenylenediamine using electrolysis system with $\mathrm{Ti} / \mathrm{TiRuO}_{2}$ electrodes. Braz. Arch. Biol. Technol., 47 (6), 983-994.

Juteau, P., Bisaillon, J-G., Lepine, F., Ratheau, V., Beaudet, R., Villemur, R. (2003), Improving the biotreatment of hydrocarbons-contaminated soils by addition of activated sludge taken from the wastewater treatment facilities of an oil refinery. Biodegradation, 14 (1), 31-40.

Kataoka, A.P.A.G. (2001), Biodegradação de resíduo oleoso de refinaria de petróleo por microorganismos isolados de "landfarming". PhD dissertation Instituto de Biociências, Unesp - Rio Claro.

Machín-Ramírez, C., Okohc, A. I., Morales, D., Mayolo-Deloisa, K., Quintero, R. and TrejoHernández, M. R. (2008), Slurry-phase biodegradation of weathered oily sludge waste. Chemosphere 70 (4), 737-744.

Mariano, A. P., Bonotto, D. M., Angelis, D. F., Pirôllo, M. P. S. and Contiero, J. (2008a), Biodegradability of commercial and weathered diesel oils. Braz. J. Microbiol. 39, 133-142.

Mariano, A. P., Tomasella, R. C., Oliveira, L. M., Contiero, J. and Angelis, D. F. (2008b), Biodegradability of diesel and biodiesel blends. African Journal of Microbiology, 7 (9), 1323-1328.

Mariano, A. P., Crivelaro, S. H. R., Angelis, D. F. and Bonotto, D. M. (2009a), The use of vinasse as an amendment to ex-situ bioremediation of soil and groundwater contaminated with diesel oil. Braz. Arch. Biol. Technol., 52 (4), 1043-1055.

Mariano, A. P., Tomasella, R. C., Di Martino, C., Maciel Filho, R., Seleghim, M. H. R., Contiero, J., Angelis, D. F. (2009b), Aerobic biodegradation of butanol and gasoline blends. Biomass and Bioenergy, 33, 1175-1181.

Mielniczuk, C. A. (1991), População microbiana e a degradação de resíduo petroquímico no solo. Master thesis - Universidade Federal do Rio Grande do Sul, Porto Alegre. 
Mishra, S., Ramesh, J. J., Kuhad, C. and Lal, B. (2001), Evaluation of inoculum addition to stimulate in situ bioremediation of oily-sludge-contaminated soil. Appl. Environ. Microbiol., 67 (4), 1675-1681.

Mrayyan, B and Battikhi, M. (2004), Biodegradation of total petroleum hydrocarbon (TPH) in Jordanian petroleum sludge. World Review of Science, Technology and Sustainable Development, 2 (1), 138150.

Prata, F., Lavorenti, A., Regitano, J. B. and Tornisielo, V. L. (2001), Degradação e sorção de ametrina em dois solos com aplicação de vinhaça. Pesq. agropec. bras., 36 (7), 975-981.

Régis, G. and Bidoia, E. D. (2005), Electrolytic treatment applied to the industrial effluent containing persistent wastes monitored by Bartha respirometric assays. Braz. Arch. Bio.Technol., 48 (2), 319-325.
Rodella, A. A., Zambello Júnior, E. and Orlando Filho, J. (1983), Effects of vinasse added to soil on $\mathrm{pH}$ and exchangeable aluminum content. Paper presented at Congress of The International Society of Sugar Cane Technologists. Havana, 1983. Proceedings. Havana: Universidad de La Habana, p. 189-214.

Ururahy, A. F. P., Marins, M. D. M., Vital, R. L., Gabardo, I. T. and Pereira Jr., N. (1998), Effect of aeration on biodegradation of petroleum waste. Rev. Microbiol., 29 (4), 254-258.
Received: June 13, 2008; Revised: February 09, 2009; Accepted: February 04, 2010. 